\title{
Phenology, Crop Stand and Biomass of Wheat in Response to Farmyard Manure and Soil Amendments
}

\section{Anjum and Ahmad Khan*}

Department of Agronomy, The University of Agriculture, Peshawar, Khyber Pakbtunkbwa, Pakistan.

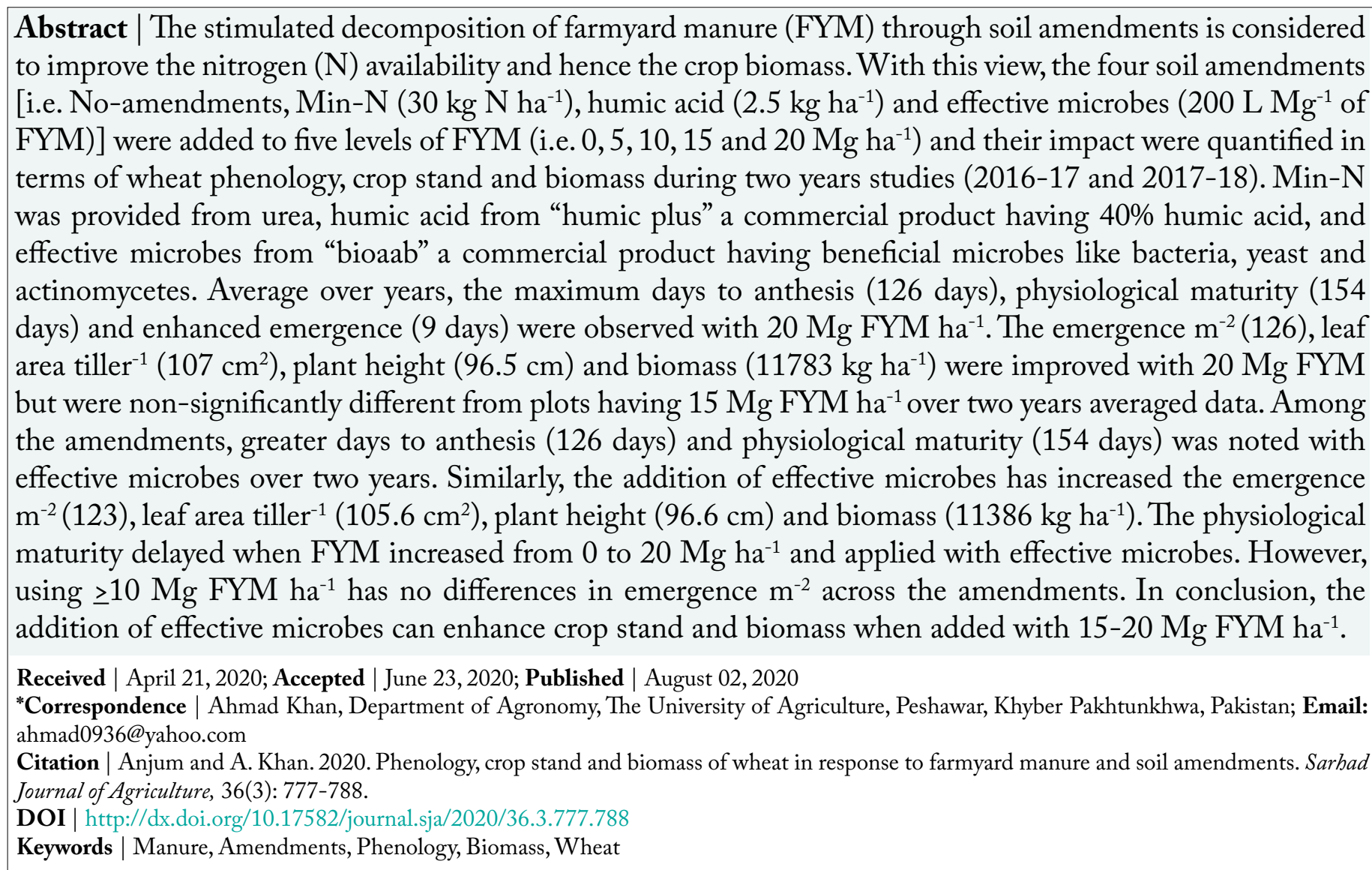

\section{Introduction}

W Theat (Triticum aestivum L.) belonging to family Poaceae and utilized for food and feed purpose. Pakistan occupies $8^{\text {th }}$ position in wheat production (Muhammad et al., 2013). It is cultivated over $42 \%$ of total cultivable land in Pakistan with average production of $2919 \mathrm{~kg} \mathrm{ha}{ }^{-1}$ (MNFSR, 2018). The average yield of wheat in Pakistan is not satisfactory for the food demands of increasing population. Pakistani nation prefer wheat over the grains crops like rice, maize, barley etc. (Muhammad et al., 2013). This low wheat productivity is being associated with low soil fertility and imbalance use of nutrients.

Frequent and continuous supply of nutrients results in improving the yield and yield parameters (Muhammad et al., 2013). Wheat needs huge amount of nutrients including nitrogen, and thus depleting 
soil fertility (Sainju et al., 2002). Due to lower N status and soil organic matter (SOM) contents of our province (Sharif et al., 2002), the farmers need chemical fertilizer for optimum and economic yield (Ahmad, 1999). The mineral $\mathrm{N}$ fertilizer can supply the required nutrients for the plants, however, it can cause environmental pollution (Mukherjee and Zimmerman, 2013). Thus, the low soil fertility problem can be eliminated by using the organic sources of nitrogen (Ibrahim et al., 2020). The organic fertilizers included manure of farm, sheep, poultry, and different commercial based derived compost. Among them, farmyard manure is a major source of nitrogen and enhance the soil fertility (Khan et al., 2019a) However, it is used in huge amount and decomposed slowly for the current crop (Muhammad et al., 2018).

The addition of fertilizer (Khan et al., 2019b), humic acid (Akhtar et al., 2014), and effective microbes (Liu et al., 2010) are considered to enhance crop production via stimulating microbial activity. The addition of $\mathrm{N}$ induced changes in soil microbial community and accelerate the biochar degradation (Schulz and Glaser, 2012). Nitrogen has a positive effect on easily degradable organic material (Sharif et al., 2002). The humic acid is a natural product and contains $51-57 \%$ organic carbon, 4-6\% nitrogen, 0.2-1\% P (Sharif et al., 2002). The greater $\mathrm{C}$ amount available in $\mathrm{HA}$ act as a food for soil microbes. The increased microbial activities decompose the manure and results in more nutrients availability and thus improve the plant growth through chelating and making available the unavailable nutrients for plants (Tahir et al., 2011). The effective microbes addition to the soil increased the decomposition of SOM (Singh et al., 2011). It is a bio-fertilizer, which increased the decomposition through stimulating microbial activities and thus had increased the crop grain yield and biomass (Khan et al., 2014). This practice is considered is eco-friendly and economical, when compared to synthetic fertilization (Singh et al., 2011). It can reduce the use of chemical fertilizer and improved the soil biota. The effective microbes efficiently decompose animal manures into available nutrients and thus increase the efficiency of organic sources of nutrients (Akhtar et al., 2014).

The enhanced microbial activity increased manure decomposition (Schulz and Glaser, 2012), which is important for the current production system in the province. However, information is limited on this important research question. Manure had increased the soil fertility and crop production. However, the slow releasing nutrients from the decomposing FYM is considered a strong obstruct in this regard. Therefore, effect of organic and inorganic amendments for improving the manure decomposition and its effects on wheat biomass and crop stand were undertaken in field studies. The objectives of the designed experiments were a) to find out the optimum level of farmyard manure for improving wheat biomass and stand establishment, b) to find out the suitable amendment for improving FYM decomposition, and its effects on wheat crop stand and biomass and c) to understand the interactive response of FYM levels and amendment for improving wheat biomass and stand establishment.

\section{Materials and Methods}

\section{Site description}

The impact of adding amendments on farmyard manure (FYM) decomposition and its effect on wheat biomass and stand establishment were carried out in field experiments. The experiments were conducted at Agricultural Research Farm, the University Agriculture Peshawar $\left(34^{\circ} \mathrm{N}, 71^{\circ} \mathrm{E}\right)$, north-west Pakistan for two consecutive years 2016-17 and 201718. The initial physico-chemical properties (before sowing) of randomly taken soil samples (20 cm depth) from five different locations are given in Table 1 . The soil was alkaline having $\mathrm{pH}(8.4)$, SOC (0.51\%), total $\mathrm{N}(0.05 \%)$, mineral N (18.24 $\left.\mathrm{mg} \mathrm{kg}^{-1}\right)$, extractable $\mathrm{P}$ $\left(2.7 \mathrm{mg} \mathrm{kg}^{-1}\right), \mathrm{K}\left(87.4 \mathrm{mg} \mathrm{kg}^{-1}\right)$ and soil bulk density $\left(1.24 \mathrm{~g} \mathrm{~cm}^{-3}\right)$. The soil of the experimental site was silt loam with sand (29.1\%), silt (55.7\%) and clay (15.2\%), piedmont alluvium and classified as Ustochrepth based on USDA classification (Anonymous, 2007). The cropping sequence in the study site was wheatmaize-wheat rotation, with inclusion of legume crop occasionally in the last 10 years. The temperature and rainfall data of the study area is presented in Figure 1 . The minimum temperatures ranged from $2.8^{\circ} \mathrm{C}$ (January, 2018) to $22.9^{\circ} \mathrm{C}$ (May, 2017) with averaged temperature of $13.5^{\circ} \mathrm{C}$, whereas maximum temperature ranged from $16.8{ }^{\circ} \mathrm{C}$ (December, 2016) to $38.4{ }^{\circ} \mathrm{C}$ (May, 2017) with averaged temperature of $28.6{ }^{\circ} \mathrm{C}$. The rainfall occurred across the growth period in both years, except in November, December 2016, as well as in January 2017. Similarly, in March in both years, the rainfall was lesser than crop water requirements. Therefore, the crop water requirements 
were met from external irrigations, when needed. A total of six irrigations were applied to the wheat crop at crown root initiation, tillering, jointing/boot, anthesis, milk and grain formation stages using flood irrigation during both years.

Table 1: The physico-chemical properties of soil and amendments used in the experiment.

$\begin{array}{lllll}\text { Properties } & \text { Units } & \text { Soil } & \text { FYM } & \begin{array}{l}\text { Humic } \\ \text { acid }\end{array} \\ \text { Organic carbon } & \% & 0.51 & 15.7 & 55.43 \\ \text { Total N } & \% & 0.05 & 1.15 & 4.75 \\ \text { Mineral N } & \mathrm{mg} \mathrm{kg}^{-1} & 18.24 & - & - \\ \text { Extractable P } & \mathrm{mg} \mathrm{kg}^{-1} & 2.70 & - & 0.72 \\ \text { Extractable K } & \mathrm{mg} \mathrm{k}^{-1} 1 & 87.41 & - & - \\ \text { pH } & & 8.04 & 8.70 & - \\ \text { Electrical conductivity } & \mathrm{dS} \mathrm{m}^{-1} & 1.69 & & - \\ \text { Moisture holding capacity } & \% & 34.21 & 51.11 & - \\ \text { Bulk density } & \mathrm{g} \mathrm{cm}{ }^{-3} & 1.24 & - & - \\ \text { Textural class } & & \text { Silt loam } & - \\ \text { Sand } & \% & 29.10 & - & - \\ \text { Silt } & \% & 55.69 & - & - \\ \text { Clay } & \% & 15.21 & - & -\end{array}$

FYM: Farmyard manure.

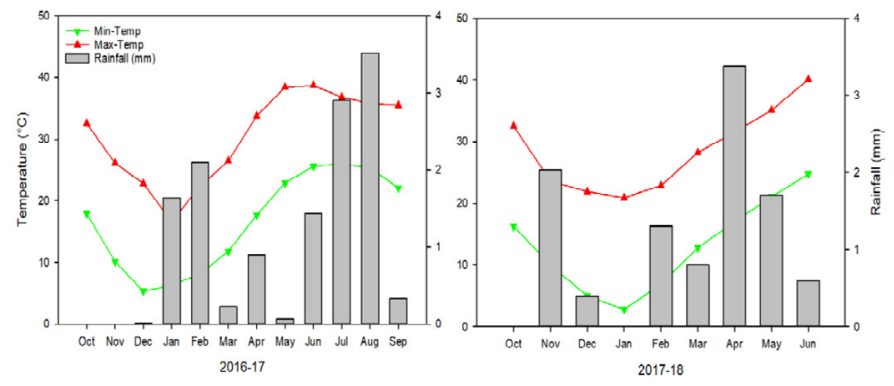

Figure 1: Climatic data (rainfall and temperature) of the experimental site during 2016-18.

Materials and treatments

Five levels of FYM (i.e. 0, 5, 10, 15, and $20 \mathrm{Mg} \mathrm{ha}^{-1}$ ) were mixed with four amendments [i.e. control (no amendment), Min-N (mineral nitrogen @30 kg N ha ${ }^{-1}$ as urea N), HA (humic acid @ $2.5 \mathrm{~kg} \mathrm{ha}^{-1}$ ) and EM (effective microbes@200 L Mg-1 of FYM).The FYM was collected from the dairy Farm, the University of Agriculture, Peshawar before the initiation of the experiments and analyzed for physico-chemical properties ( $\mathrm{SOC}, \mathrm{pH}$, total $\mathrm{N}$ ) with the detail given in Table 1. Min-N amendment was supplied from synthetic fertilizer i.e. urea $(46 \% \mathrm{~N})$, humic acid from "humic plus" having $40 \%$ humic acid and $7 \%$ $\mathrm{K}_{2} \mathrm{O}$ available as commercial product of Al-Hameed Chemicals Pvt limited. The effective microbes were supplied from "Bioaab" a commercial product of NFRDF NGO prepared with collaboration with the Faculty of Agriculture, The University of FaisalabadPakistan. The bioaab contained Rhodopseudomona ssp., Lactobacillus sp., Saccharomyces sp. and Actinomycetes etc. and molasses as media. The effective microbe solution was prepared by using $2 \%$ of commercial product "bioaab" and 98\% distilled water. The different organic amendments (humic acid and bioaab i.e. effective microorganisms) and inorganic amendment (mineral nitrogen in the form of urea) was mixed with FYM according to the given rates, and thereafter was applied to the respective plots. However, in case of no-amendments, an equivalent amount of water was added to the FYM to nullify the effect of added water on FYM decomposition.

\section{Experimentations}

The experiments were laid out in RCB design with four replications. The field was ploughed 2-3 times using common cultivator at proper field capacity level. The treatments were allotted to the respective plots after field layout, 25-30 days before sowing and were irrigated if needed for maintaining field capacity till sowing of crop. The plots size was $3 \times 5 \mathrm{~m}$, having 10 rows $30 \mathrm{~cm}$ apart and $5 \mathrm{~m}$ long. 25-30 days after treatments imposition, the field was ploughed using rotavtor for seed bed preparation. Spring wheat (cv. Pirsabak-2013) was sown on $21^{\text {st }}$ November in 2016 for first wheat crop and $11^{\text {th }}$ November in 2017 for $2^{\text {nd }}$ wheat crop at the seed rate of $120 \mathrm{~kg} \mathrm{ha}^{-1}$. In addition to the $\mathrm{N}$ fertilizers, basal doses of $\mathrm{P}$ and $\mathrm{K}$ were applied to the soil @60 kg ha-1 at time of sowing. Weeding, hoeing and irrigation (a total of six, mentioned above) were carried out uniformly for all plots.

\section{Observations and measurements}

Random soil samples (20 cm depth) were made from five locations from the whole experimental plot and composited before wheat plantation. The composite samples were brought to laboratory. Fresh soil samples (manually removed stones and debris) were used for mineral $\mathrm{N}$ determination. Whereas the remaining parts of the samples were air dried and grinded with grinder (Kinematic, Switzerland) of $2 \mathrm{~mm}$ mesh size, and was store for $\mathrm{N}, \mathrm{C}, \mathrm{pH}$ and $\mathrm{EC}$ determinations. The mineral $\mathrm{N}$ determination was carried out according to Keeney and Nelson (1982). Soil total $\mathrm{N}$ was measured by the procedure of Bremner and Mulvaney (1982) following Kjeldahl principle, and Organic $\mathrm{C}$ by the modified method of Nelson and 
Sommers (1982). The soil $\mathrm{pH}$ was recorded using the Mclean (1982) method of 1:5 (soil: water) suspension, whereas the soil bulk density was measured with Black and Hartge (1984) procedure.

Seedling emergence was observed daily from date of sowing till completion of $80 \%$ seedling emergence in each plot. Days to emergence data was recorded as the difference between sowing date and the date when $80 \%$ emergence occurred in each plot. Seedlings were counted in three locations at random across onemeter length in central three rows when $80 \%$ of plants emerged, and emergence $\mathrm{m}^{-2}$ were thus derived using the formula:

$$
\text { Emergence } m^{-2}=\frac{\text { Seedling counted }}{\text { Row }- \text { Row } \times \text { No. of rows } \times \text { row length }} \times 1
$$

Days to anthesis and physiological maturity were counted from sowing date till completion of $80 \%$ anthesis and maturity in each plot, respectively. The yellowing of leaves and spike was considered criteria for determination of physiological maturity in wheat. The height of five plants at random from base to tip excluding awns were taken with measuring rod, averaged and taken plant height of wheat. At harvest maturity, the central six rows were harvested in each plot, and sun dried for a week in the field to determine the biomass. The dried material was weighed and expressed in $\mathrm{kg} \mathrm{ha}^{-1}$ using the formula, after correcting the moisture contents.

$$
\text { Biomass }\left(\mathrm{kg} \mathrm{ha}^{-1}\right)=\frac{\text { Biomass of six rows }}{\text { Row }- \text { Row } \times \text { No. of rows } \times \text { row length }} \times 10,000
$$

\section{Statistical analysis}

The collected data were analyzed statistically as per the procedure of the RCB design over years. Means were separated using least significant difference (LSD) test upon significant F-test with a probability values of 5\% (Jan et al., 2009).

\section{Results and Discussion}

\section{Phenological observations}

Days to emergence of wheat averaged over years were significantly $(\mathrm{p} \leq 0.05)$ varied with FYM application and non-significantly affected by soil amendments and years (Table 2). However, during the first year (2016-17), no differences in days to emergence were noted among FYM, amendments or its interaction. Averaged over years data shows that minimum days to emergence were recorded with 15 and $20 \mathrm{Mg}$ FYM ha ${ }^{-1}$ (9 days) application while no difference was measured with other levels. However, with amendments application, no difference was recorded with No-amendments, Min-N and humic acid while the days to emergence was non-significantly ( $p \leq$ $0.05)$ less with effective microbes (9 days). Anthesis of wheat varied significantly $(\mathrm{p} \leq 0.05)$ with FYM application and soil amendments both in individual years as well as averaged over years (Table 2). The days to anthesis of wheat delayed by one day in the $2^{\text {nd }}$ year as compared to first year (Table 2). The $20 \mathrm{Mg}$ FYM $\mathrm{ha}^{-1}$ had delayed the wheat anthesis by 2 days over the No FYM addition over both years. A single day delay in anthesis was observed with Min-N, humic acid and effective microbes as compared to No-amendments (124 days) across the years. Physiological maturity was delayed by 2 days in year-II as compared to year-I (Table 2). The wheat physiological maturity delayed from 151 to 153 days with increasing FYM from 0 to $20 \mathrm{Mg} \mathrm{ha}^{-1}$ averaged over two years data (Table 2). Similarly, with amendments application (Table 2), maximum days to physiological maturity was taken with Min-N application (153 days) over No-amendments (151 days) over two years data. The interaction of FYM with soil amendments (Figure 2) shows that increasing the FYM from 0 to 20 $\mathrm{Mg} \mathrm{ha}^{-1}$, the physiological maturity delayed with No-amendments and effective microbes. However, with humic acid or Min-N as soil amendments, the physiological maturity did not change with increasing FYM levels from 0 to $20 \mathrm{Mg} \mathrm{ha}^{-1}$.

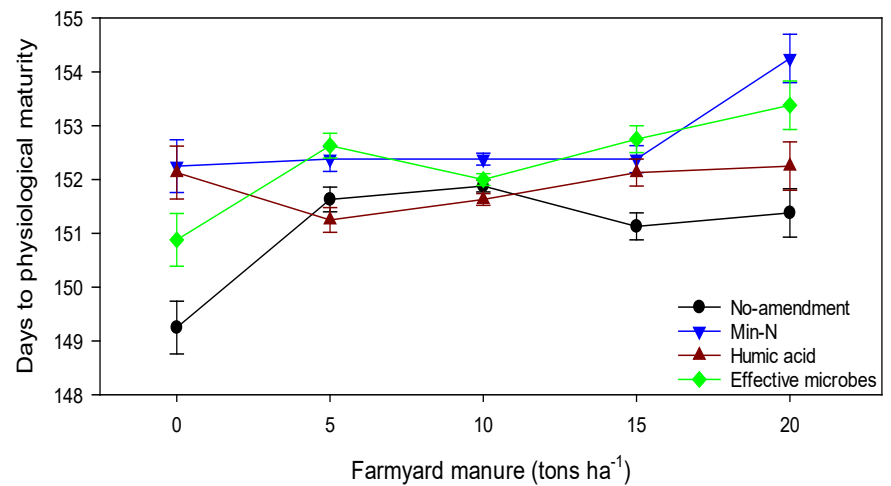

Figure 2: Days to physiological maturity of wheat in response to $F Y M \times$ Amendments interaction over years. The vertical bars are standard error of means $(n=4)$.

\section{Crop growth and stand}

The leaf area tiller ${ }^{-1}$ was significantly $(\mathrm{P} \leq 0.05)$ affected by FYM and amendments application both in individual years as well as averaged over two years data (Table 3). However, all the interactions 
was found not significant. The leaf area tiller ${ }^{-1}$ was significantly higher in the $2^{\text {nd }}$ year $\left(100.8 \mathrm{~cm}^{2}\right)$ as compared to first year $\left(97.4 \mathrm{~cm}^{2}\right)$. Data of two years average for leaf area tiller ${ }^{-1}$ (Table 3 ) shows that FYM addition significantly $(\mathrm{p} \leq 0.05)$ improved leaf area tiller $^{-1}$. Increasing FYM level from 0 to $15 \mathrm{Mg} \mathrm{ha}^{-1}$ had increased the leaf area from 89.9 to $103.5 \mathrm{~cm}^{2}$ showing $15 \%$ increases. However, the latter was not significantly $(p \leq 0.05)$ different from leaf area tiller ${ }^{-1}$ noted with $20 \mathrm{Mg}$ FYM ha-1 $\left(105.9 \mathrm{~cm}^{2}\right)$. Among the amendments, leaf area tiller ${ }^{-1}$ was maximum with effective microbes $\left(102.9 \mathrm{~cm}^{2}\right.$ tiller-1) as compared to No-amendments $\left(93.5 \mathrm{~cm}^{2}\right.$ tiller $\left.^{-1}\right)$. Data regarding plant height (Table 3), showed significant differences $(\mathrm{p} \leq 0.05)$ for the plant height due to FYM addition both in individual years as well as averaged over two years data. The plant height was maximum with 20 Mg FYM ha ${ }^{-1}(96.5 \mathrm{~cm})$ and minimum with 0-ton FYM ha ${ }^{-1}(91.0 \mathrm{~cm})$ averaged over two years data. However, the plants height was non-significantly affected by amendments in first year (2016-17) but varied significantly $(P \leq 0.05)$ in the $2^{\text {nd }}$ year (2017-18) and averaged over two years data. With amendments addition maximum plant height was recorded with effective microbes and Min-N (95.4 and $94.9 \mathrm{~cm}$, respectively) followed by humic acid $(94.0 \mathrm{~cm})$ and minimum plant height was recorded with No-amendments $(92.8 \mathrm{~cm})$ over two years data.

The application of FYM had significantly $(\mathrm{P} \leq 0.05)$ affected emergence $\mathrm{m}^{-2}$ both in individual year as well as averaged over two years data. However, the amendments application had not significantly ( $\mathrm{P} \leq$ $0.05)$ affected the emergence $\mathrm{m}^{-2}$ in year-1 (2016-17), but had significant $(\mathrm{P} \leq 0.05)$ effects on emergence $\mathrm{m}^{-2}$ of wheat in $2^{\text {nd }}$ years as well was averaged over two years data (Table 3). No statistical differences for wheat emergence $\mathrm{m}^{-2}$ was noted between years 1 and year 2 (Table 3). A total of $11 \%$ increases in emergence $\mathrm{m}^{-2}$ were documented with increasing the FYM from 0 to $20 \mathrm{Mg} \mathrm{ha}^{-1}$ based on two years data (Table 3). With amendments addition, no significant $(p \leq 0.05)$ difference in emergence $\mathrm{m}^{-2}$ was noted with Min-N (119), humic acid (120) and effective microbes (121) as compared to No-amendments (114). The FYM x amendments interaction (Figure 3) shows that emergence $\mathrm{m}^{-2}$ sharply increased with $\mathrm{No}^{-}$ amendments as compared to Min- $\mathrm{N}$ with increasing FYM from 0 to $10 \mathrm{Mg}^{-1}$. Using $10 \mathrm{Mg}$ FYM $\mathrm{ha}^{-1}$ or above, no differences in emergence $\mathrm{m}^{-2}$ was noted among the amendments like No-amendments,
Min-N or humic acid, however, the emergence was higher with effective microbes across the FYM levels.

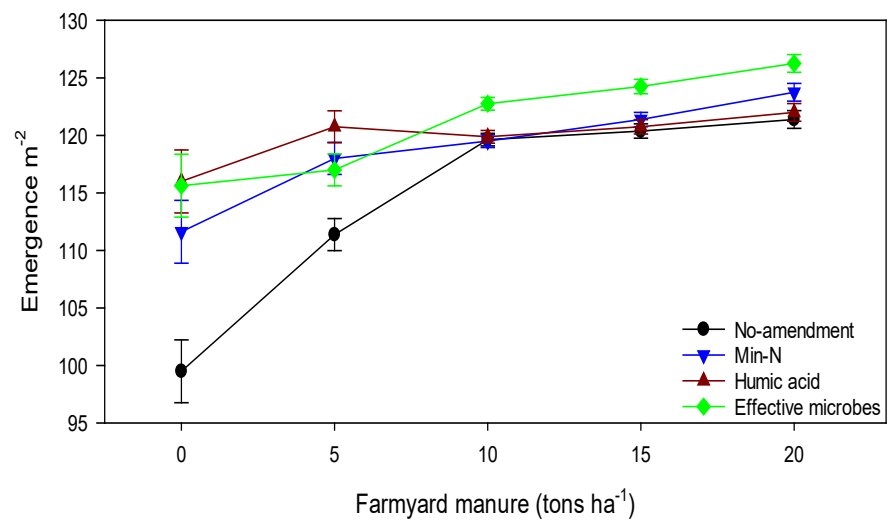

Figure 3: Emergence $m^{-2}$ of wheat in response to FYM $\times$ Amendments interaction over years. The vertical bars are standard error of means $(n=4)$.

\section{Crop biomass $\left(\mathrm{kg} \mathrm{ha}^{-1}\right)$}

Biomass of wheat was significantly $(\mathrm{p} \leq 0.05)$ higher in the following year $\left(10620 \mathrm{~kg} \mathrm{ha}^{-1}\right)$ than the first year $\left(10014 \mathrm{~kg} \mathrm{ha}^{-1}\right)$ as shown in Table 4. During 2016-17, FYM application significantly ( $p \leq 0.05$ ) improved the biomass with all levels. Maximum biomass was observed with 15 and $20 \mathrm{Mg}$ FYM ha ${ }^{-1}$ (10484 and $10453 \mathrm{~kg} \mathrm{ha}^{-1}$, respectively) than No FYM $\mathrm{ha}^{-1}\left(9204 \mathrm{~kg} \mathrm{ha} \mathrm{ha}^{-1}\right)$. With amendments addition, no significant $(p \leq 0.05)$ difference in biomass was found among the amendments like No-amendments (9750 kg ha-1), Min-N (9781 kg ha-1) and humic acid (10027 kg ha-1) but were significantly lower than effective microbes $\left(10561 \mathrm{~kg} \mathrm{ha}^{-1}\right)$ were nonsignificant. In 2017-18, wheat biomass ranged from 9523 (No FYM) to $11783 \mathrm{~kg} \mathrm{ha}^{-1}\left(20 \mathrm{Mg} \mathrm{ha}^{-1}\right)$. With amendments addition maximum biomass produced with application of effective microbes $(11386 \mathrm{~kg}$ ha $\left.{ }^{1}\right)$ over No-amendments $\left(9838 \mathrm{~kg} \mathrm{ha}^{-1}\right)$. Two years average data shows that biomass increased by $19 \%$ with $20 \mathrm{Mg}$ FYM ha ${ }^{-1}$ than No- FYM. However, the biomass produced in plots having either 15 or $20 \mathrm{Mg}$ FYM ha ${ }^{-1}$ were non-significant and produced 10888 and $11118 \mathrm{~kg}$ biomass $\mathrm{ha}^{-1}$, respectively. Maximum biomass was produced with addition of effective microbes (10973 kg ha ${ }^{-1}$ ) than No-amendments (9794 $\mathrm{kg} \mathrm{ha}^{-1}$ ) across the two years averaged data.

\section{Phenological observations}

The seedling emergence depends on the internal stored food in the cotyledon (Saharan et al., 2016), optimum temperature (Zavattaro et al., 2017) and moisture availability (Saikia et al., 2015). The plant took less days to emergence in plots where 15 and $20 \mathrm{Mg}$ 
Table 2: Phenological observations (days) of wheat as affected by farmyard manure addition modulated by various amendments during 2016-17 (Year I) and 2017-18 (Year II).

\section{Treatments}

Farmyard manure (FYM, $\mathrm{Mg} \mathrm{ha}^{-1}$ )

0

5

10

15

20

$\mathrm{LSD}_{0.05}$

Amendments (A)

No-amendments

Min-N

Humic acid

Effective microbes

$\mathrm{LSD}_{0.05}$

Means of the years

Significance

Years $(Y)$

FYM

A

$\mathrm{FYM} \times \mathrm{A}$

$\mathrm{Y} \times \mathrm{FYM}$

$\mathrm{Y} \times \mathrm{A}$

$\mathrm{Y} \times \mathrm{FYM} \times \mathrm{A}$

\section{Phenological observations (days)}

\begin{tabular}{lllllllll}
\multicolumn{3}{c}{ Emergence } & \multicolumn{3}{c}{ Anthesis } & \multicolumn{3}{c}{ Maturity } \\
Year I & Year II & Mean & Year I & Year II & Mean & Year I & Year II & Mean \\
$10 \mathrm{a}$ & $10 \mathrm{a}$ & $10 \mathrm{a}$ & $123 \mathrm{~d}$ & $124 \mathrm{c}$ & $124 \mathrm{c}$ & $151 \mathrm{~b}$ & $152 \mathrm{c}$ & $151 \mathrm{c}$ \\
$10 \mathrm{a}$ & $10 \mathrm{a}$ & $10 \mathrm{a}$ & $124 \mathrm{c}$ & $124 \mathrm{c}$ & $124 \mathrm{c}$ & $151 \mathrm{~b}$ & $153 \mathrm{~b}$ & $152 \mathrm{~b}$ \\
$10 \mathrm{a}$ & $9 \mathrm{~b}$ & $10 \mathrm{a}$ & $124 \mathrm{c}$ & $125 \mathrm{~b}$ & $125 \mathrm{~b}$ & $151 \mathrm{~b}$ & $153 \mathrm{~b}$ & $152 \mathrm{~b}$ \\
$10 \mathrm{a}$ & $9 \mathrm{~b}$ & $9 \mathrm{~b}$ & $125 \mathrm{~b}$ & $126 \mathrm{a}$ & $125 \mathrm{~b}$ & $152 \mathrm{a}$ & $153 \mathrm{~b}$ & $152 \mathrm{~b}$ \\
$9 \mathrm{a}$ & $9 \mathrm{~b}$ & $9 \mathrm{~b}$ & $126 \mathrm{a}$ & $126 \mathrm{a}$ & $126 \mathrm{a}$ & $152 \mathrm{a}$ & $154 \mathrm{a}$ & $153 \mathrm{a}$ \\
NS & 0.7 & 0.6 & 0.9 & 0.9 & 0.6 & 0.8 & 1.0 & 0.6
\end{tabular}

$\begin{array}{lllllllll}10 \mathrm{a} & 10 \mathrm{a} & 10 \mathrm{a} & 123 \mathrm{c} & 124 \mathrm{c} & 124 \mathrm{~b} & 151 \mathrm{a} & 151 \mathrm{c} & 151 \mathrm{c}\end{array}$

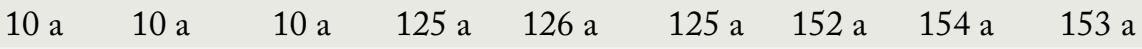

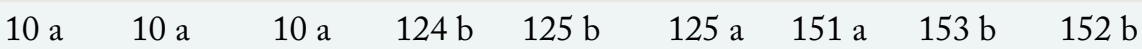

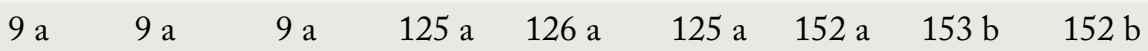

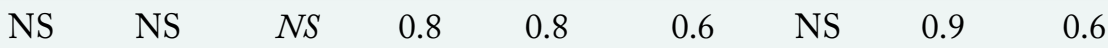

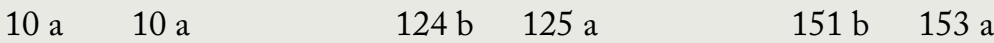

NS
NS
NS
NS
NS
NS

$\begin{array}{ll}* * & - \\ * * & * \\ * * & \text { NS } \\ \text { NS } & \text { NS } \\ \text { NS } & - \\ \text { NS } & - \\ \text { NS } & -\end{array}$

$\begin{array}{ll}- & * * \\ * * & * * \\ * & * * \\ * & * \\ - & \text { NS } \\ - & \text { NS } \\ - & \text { NS }\end{array}$

Min-N was added @30 kg N ha-1; Humic acid @2.5 ha $a^{-1}$; Effective microbes@200L Mg-1 FYM; NS: Non-significant at P $\leq$ 0.05; * Significant at $P \leq 0.05$ and ${ }^{*}$ Significant at $P \leq 0.01$. Means within each category sharing common letter (s) are non-significant at $p \leq 0.05$ following LSD test.

FYM ha ${ }^{-1}$ were applied than No FYM addition. The addition of FYM in the following year, and the accumulated manure from the last year might have increased the soil permeability, made the soil surface soft for emergence in addition to increase soil moisture (Saikia et al., 2015) and regulated soil temperature (Li et al., 2013), and thus had decreased days to emergence of wheat.

Wheat anthesis entirely depends on vegetative growth (Zhang et al., 2015), which itself is affected by nutrients availability (Khan et al., 2019a) and crop stand (Ibrahim and Khan, 2017). It was observed that increasing the FYM had increased the mineral $\mathrm{N}$ availability (Khan et al., 2019a), and other macro and micronutrients (Bowles et al., 2014), and thus had delayed the anthesis stage. The addition of Min-N itself (Khan et al., 2009) or increased $\mathrm{N}$ availability as a result of improved microbial activity in response to effective microbes addition (Mukherjeeand Zimmerman, 2013) had increased soil mineral $\mathrm{N}$
(Khan et al., 2019a), thereby increased the vegetative growth (Ibrahim and Khan, 2017; Khan et al., 2019b) and thus anthesis delayed. The increased root growth with increasing the nutrients (Zhang et al., 2015) may be another possible explanation for increased vegetative growth and delayed anthesis.

The physiological maturity is directly related to the environmental temperature (Olesen et al., 2012) and indirectly to the plant vegetative growth (Khan et al., 2008). The addition of higher levels of FYM had increased the nutrients availability particularly the nitrogen (Khan et al., 2019a), which increased the leaf vegetative growth (Khan et al., 2019b), and thus prolonged the days to physiological maturity stage in wheat. The repeated addition of effective microbes had increased the soil microbial biomass (Ali et al., 2019), increased the nutrients availability (Khan et al., 2019a), which delayed the vegetative growth (Khan et al., 2019b) and thus might have increased the days taken to physiological maturity. The addition of 
Table 3: Growth and stand of wheat as affected by farmyard manure addition modulated by various amendments during 2016-17 (Year I) and 2017-18 (Year II).

\section{Treatments}

Crop growth and stand establishment

\begin{tabular}{|c|c|c|c|c|c|c|c|c|c|}
\hline \multirow[b]{2}{*}{ Farmyard manure (FYM, $\mathrm{Mg} \mathrm{ha}^{-1}$ ) } & \multicolumn{3}{|c|}{ Leaf area tiller-1 $\left.{ }^{-1} \mathrm{~cm}^{2}\right)$} & \multicolumn{3}{|c|}{ Plant height (cm) } & \multicolumn{3}{|c|}{ Emergence $\mathrm{m}^{-2}$} \\
\hline & Year I & Year II & Mean & Year I & Year II & Mean & Year I & Year II & Mean \\
\hline 0 & $90.2 \mathrm{~d}$ & $89.7 \mathrm{~d}$ & $89.9 \mathrm{~d}$ & $90.6 \mathrm{~d}$ & $91.4 \mathrm{~b}$ & $91.0 \mathrm{~d}$ & $112 \mathrm{~b}$ & $109 c$ & $111 \mathrm{c}$ \\
\hline 5 & $93.6 \mathrm{~cd}$ & $98.5 \mathrm{c}$ & $96.1 \mathrm{c}$ & $93.0 \mathrm{c}$ & $94.3 \mathrm{ab}$ & $93.6 \mathrm{c}$ & 119 a & $115 \mathrm{~b}$ & $117 \mathrm{~b}$ \\
\hline 10 & $97.8 \mathrm{bc}$ & $102.1 \mathrm{bc}$ & $100.0 \mathrm{~b}$ & $94.1 \mathrm{bc}$ & $95.0 \mathrm{a}$ & $94.5 \mathrm{bc}$ & $119 \mathrm{a}$ & $122 \mathrm{a}$ & $120 \mathrm{ab}$ \\
\hline 15 & $101.2 \mathrm{ab}$ & $105.7 \mathrm{ab}$ & $103.5 \mathrm{a}$ & $95.6 \mathrm{ab}$ & $95.7 \mathrm{a}$ & $95.7 \mathrm{ab}$ & $120 \mathrm{a}$ & $123 \mathrm{a}$ & $122 \mathrm{a}$ \\
\hline 20 & $104.0 \mathrm{a}$ & $107.8 \mathrm{a}$ & $105.9 \mathrm{a}$ & $96.4 \mathrm{a}$ & $96.5 \mathrm{a}$ & $96.5 \mathrm{a}$ & $121 \mathrm{a}$ & $126 \mathrm{a}$ & $123 \mathrm{a}$ \\
\hline $\mathrm{LSD}_{0.05}$ & 4.8 & 5.0 & 3.5 & 2.2 & 2.8 & 1.8 & 5 & 4 & 3 \\
\hline \multicolumn{10}{|l|}{ Amendments (A) } \\
\hline No-amendments & $93.7 \mathrm{~b}$ & $93.4 \mathrm{~b}$ & $93.5 \mathrm{c}$ & $93.3 \mathrm{a}$ & $92.3 \mathrm{~b}$ & $92.8 \mathrm{~b}$ & $115 \mathrm{a}$ & $114 \mathrm{c}$ & $114 \mathrm{~b}$ \\
\hline Min-N & $96.4 \mathrm{ab}$ & $101.1 \mathrm{a}$ & $98.8 \mathrm{~b}$ & $94.7 \mathrm{a}$ & $95.1 \mathrm{a}$ & $94.9 \mathrm{a}$ & $119 \mathrm{a}$ & $119 \mathrm{~b}$ & $119 \mathrm{a}$ \\
\hline Humic acid & $99.2 \mathrm{a}$ & $102.9 \mathrm{a}$ & $101.1 \mathrm{ab}$ & $93.6 \mathrm{a}$ & $94.4 \mathrm{ab}$ & $94.0 \mathrm{ab}$ & $120 \mathrm{a}$ & $120 \mathrm{ab}$ & $120 \mathrm{a}$ \\
\hline Effective microbes & $100.2 \mathrm{a}$ & $105.6 \mathrm{a}$ & $102.9 \mathrm{a}$ & $94.2 \mathrm{a}$ & $96.6 \mathrm{a}$ & $95.4 \mathrm{a}$ & $120 \mathrm{a}$ & $123 \mathrm{a}$ & $121 \mathrm{a}$ \\
\hline $\mathrm{LSD}_{0.05}$ & 4.3 & 4.5 & 3.1 & NS & 2.5 & 1.6 & NS & 4 & 3 \\
\hline Means of the years & $97.4 \mathrm{~b}$ & $100.8 \mathrm{a}$ & & $93.9 \mathrm{a}$ & $94.6 \mathrm{a}$ & & $118 \mathrm{a}$ & $119 \mathrm{a}$ & \\
\hline \multicolumn{10}{|l|}{ Significance } \\
\hline Years (Y) & - & - & ** & - & - & NS & - & - & NS \\
\hline FYM & *** & $* *$ & ** & $*$ & $* *$ & $* *$ & $*$ & $* *$ & *** \\
\hline A & $*$ & $* *$ & $* *$ & NS & $*$ & $*$ & NS & $* *$ & ** \\
\hline $\mathrm{FYM} \times \mathrm{A}$ & NS & NS & NS & NS & NS & NS & NS & $* *$ & * \\
\hline $\mathrm{Y} \times \mathrm{FYM}$ & - & - & NS & - & - & NS & - & - & * \\
\hline $\mathrm{Y} \times \mathrm{A}$ & - & - & NS & - & - & NS & - & - & NS \\
\hline $\mathrm{Y} \times \mathrm{FYM} \times \mathrm{A}$ & - & - & NS & - & - & NS & - & - & NS \\
\hline
\end{tabular}

Min-Nwas added @ $30 \mathrm{~kg} N \mathrm{ha} \mathrm{a}^{-1}$; Humic acid @ $2.5 \mathrm{ha}^{-1}$; Effective microbes @ 200 L Mg-1 FYM; NS: Non-significant at P $\leq$ 0.05; " Significant at $P \leq 0.05$ and Significant at $P \leq 0.01$. Means within each category sharing common letter (s) are non-significant at $p \leq 0.05$ following LSD test.

effective microbes had stimulated the decomposition of added manure and thus had increased the nutrients availability (Liu et al., 2010), improved the vegetative growth (Khan et al., 2019b) due to transferring of the metabolites and its translocation to the vegetative tissues (Khan et al., 2014) and thus might have prolonged the period for days to physiological maturity.

\section{Crop growth and stand establishment}

Increasing FYM from 0 to $20 \mathrm{Mg} \mathrm{ha}^{-1}$ had improved the leaf area by $15-20 \%$. The increased manure application means increasing the net nitrogen and other nutrients availability upon decomposition. The increased availability of mineral $\mathrm{N}$ increased the photosynthetic efficiency of the plants (Akhtar et al., 2019b; Khan et al., 2019b) and thus increase the cell size and number (Keller and Koblet, 2015), and thus the leaf area of plants. The effective microbes had increased the mineralization of manure, and thereby increased the nutrients availability (Pan et al., 2018), which improved the leaf areas due to the vagarious crop growth.

Plant tallness depends on the vigorous plant growth and development (Walker et al., 2004). The increased nutrients availability as a result of greater manure addition increased the nutrients uptake (Akhtar et al., 2019c; Wen et al., 2016), photosynthetic efficiency (Saikia et al., 2015), and thus the plant height. The addition of effective microbes has increased the plant tallness by $5 \%$ over No-amendment. The effective microbes had increased the decomposition and increased the nutrients availability (Fang et al., 2018). The higher nutrients availability might have improved the vegetative growth of plants (Wen et al., 2016), increased the leaf area (Keller and Koblet, 2015), and thus had increased the plant tallness. 
Table 4: Biomass $\left(\mathrm{kg} \mathrm{ha}^{-1}\right)$ of wheat as affected by farmyard manure (FYM) addition modulated by various amendments over years.

\begin{tabular}{llll} 
Treatments & \multicolumn{2}{c}{ Years (Y) } & Mean \\
FYM (tons ha $\left.{ }^{-1}\right)$ & $2016-17$ & $2017-18$ & \\
0 & & & \\
5 & $9204 \mathrm{c}$ & $9523 \mathrm{c}$ & $9363 \mathrm{~d}$ \\
10 & $9821 \mathrm{~b}$ & $9838 \mathrm{c}$ & $9829 \mathrm{c}$ \\
15 & $10109 \mathrm{ab}$ & $10666 \mathrm{~b}$ & $10387 \mathrm{~b}$ \\
20 & $10484 \mathrm{a}$ & $11292 \mathrm{ab}$ & $10888 \mathrm{a}$ \\
LSD $_{0.05}$ & $10453 \mathrm{a}$ & $11783 \mathrm{a}$ & $11118 \mathrm{a}$ \\
Amendments (A) & 558 & 735 & 465 \\
No-amendments $^{-}$ & $9750 \mathrm{~b}$ & $9838 \mathrm{c}$ & $9794 \mathrm{c}$ \\
Min-N & $9718 \mathrm{~b}$ & $10517 \mathrm{~b}$ & $10118 \mathrm{bc}$ \\
Humic acid & $10027 \mathrm{~b}$ & $10741 \mathrm{ab}$ & $10384 \mathrm{~b}$ \\
Effective microbes & $10561 \mathrm{a}$ & $11386 \mathrm{a}$ & $10973 \mathrm{a}$ \\
LSD & & & \\
Me.05 & 499 & 658 & 416 \\
Y & $10014 \mathrm{~b}$ & $10620 \mathrm{a}$ & \\
FYM & - & - & $* *$ \\
A & $* *$ & $* *$ & $* *$ \\
FYM $\times$ A & $* *$ & $* *$ & $* *$ \\
Y $\times$ FYM & NS & NS & NS \\
Y $\times$ A & - & - & NS \\
Y $\times$ FYM $\times$ A & - & - & NS \\
& - & - & NS
\end{tabular}

Min-Nwas added@30 kg N ha-1; Humic acid@2.5 ha-1. Effective microbes@200 L Mg $\mathrm{Mg}^{-1}$ FYM. NS: Non-significant at P $\leq 0.05$; * Significant at $P \leq 0.05$ and ${ }^{* *}$ Significant at $P \leq 0.01$. Means within each category sharing common letter (s) are non-significant at $p \leq$ 0.05 following $L S D$ test.

Crop emergence $\mathrm{m}^{-2}$ entirely depends on seed vigor and its germination (Vashisth and Nagarajan, 2010), soil physical condition like moisture availability and temperature (Lin et al., 2019) etc. The addition of FYM had improved the soil moisture, regulated soil temperature (Zavattaro et al., 2017) and improved soil properties (Odlare et al., 2008), and thus might have improved the wheat emergence $\mathrm{m}^{-2}$. The repeated application of FYM over two years had changed the soil physico-chemical properties like improvement in soil moisture content, infiltration, bulk density (Guo et al., 2016) and porosity (Abbas and Fares, 2009), consequently, the seed germination and emergence increased. Emergence $\mathrm{m}^{-2}$ sharply increased with $\mathrm{No}^{-}$ amendments as compared to Min- $\mathrm{N}$ with increasing FYM from 0 to $10 \mathrm{Mg} \mathrm{ha}{ }^{-1}$. However, using $10 \mathrm{Mg}$ FYM ha ${ }^{-1}$ or above, no differences in emergence $\mathrm{m}^{-2}$ was noted among the amendments. This indicates that even $10 \mathrm{Mg}$ FYM ha- ${ }^{-1}$ can cause enough changes in soil properties over two years, that can increase emergence of plants.

\section{Wheat biomass}

The biomass was significantly $(\mathrm{p} \leq 0.05)$ higher in year-II than year-I. The repeated addition of manure and its residual effect (Grant et al.,2016) has increased the nutrients availability (Khan et al., 2019a)and hence the plant vegetative growth and dry matter production (Khan etal.,2014) and biomass production. In both years, the FYM application significantly ( $\mathrm{p} \leq$ 0.05 ) improved the biomass with all levels of FYM. Increasing the FYM up to $15 \mathrm{Mg} \mathrm{ha}^{-1}$ had significantly $(\mathrm{p} \leq 0.05)$ increased the biomass $(13.9 \%)$ in year-I, however in year-II, the increases were $23.7 \%$ when FYM increased from 0 to $20 \mathrm{Mg} \mathrm{ha}{ }^{-1}$. The higher manure addition assumed to have improved the soil properties including physico-chemical and biological (Akhtar et al., 2019a), increased nutrients availability (Akhtar et al., 2019c), and thereby improved the photosynthetic activity (Saikia et al., 2015), plant dry matter (Khan et al., 2014) and hence the biomass production. The addition of effective microbes has significantly $(p \leq 0.05)$ increased the biomass over humic acid, Min-N or No-amendments treatment in Year-I. However, in year-II, the organic amendments had significantly $(\mathrm{p} \leq 0.05)$ higher biomass than Min-N and No-amendments. The effective microbes increased the microbial biomass (Liu et al., 2010) and hence availability of nutrients via stimulated decomposition (Odlare et al., 2008). The increased nutrients have greater potential for improving the plant growth and development (Khan et al., 2014) via increasing the photosynthetic activities (Khan et al., 2015), and hence the biomass production. The other possible reasons for improving the biomass is the improvement in soil properties (Khan et al., 2019a), rhizosphere condition and usage efficiencies of the nutrients (Federolf et al., 2016). Biomass production is a function of individual plant performance, and thus addition of microbes has increased the individual plant performance, thus had increased the biomass.

\section{Conclusions and Recommendations}

It was concluded that increasing the FYM from 0 to $15 \mathrm{Mg} \mathrm{ha}^{-1}$, the phenological observation delayed, but the wheat leaf area, stand establishment and biomass increased. However, with further increase in FYM, no statistical $(\mathrm{P} \leq 0.05)$ differences in plants 
measured parameters were noted. Quantitatively, the physiological maturity delayed by 2 days with 20 $\mathrm{Mg}$ FYM ha ${ }^{-1}$ over No FYM. However, the leaf area increased by $17 \%$ and biomass by $16 \%$, with increasing FYM from 0 to $15 \mathrm{Mg} \mathrm{ha}^{-1}$. Likewise, the addition of effective microbes has prolonged the phenological observation and improved wheat leaf area, stand establishment and biomass. It was noted that the plant performance in term of delayed phenology, and improved growth/biomass was in the order of min-N $>\mathrm{HA} \sim \mathrm{EM}>$ no-amendment. The application of 15$20 \mathrm{Mg} \mathrm{FYM} \mathrm{ha}{ }^{-1}$ amended with effective microbes is recommended for improved crop growth and stand establishment of wheat in the studied areas.

\section{Novelty Statement}

Crop stand and biomass improved with effective microbes and manure addition Phenological observation delayed with increasing farmyard manure. The addition of effective microbes enhanced crop stand and biomass when added with 15-20 Mg FYM ha ${ }^{-1}$

\section{Author's Contribution}

Anjum carried out research and drafted the manuscript. A. Khan carried out the analysis, conceived the idea and supervised the research.

\section{Conflict of interest}

The authors have declared no conflict of interest.

\section{References}

Abbas, F. and A. Fares. 2009. Soil organic carbon and carbon dioxide emission from an organically amended hawaiian tropical soil. Soil Sci. Soc. Am. J., 73: 995-1003. https://doi.org/10.2136/ sssaj2008.0242

Ahmad, N., 1999. Fertilizer scenario in Pakistan policies and development: Agriculture and fertilizer use. Islamabad Natl. Fert. Dev. Centre. pp. 15-16.

Akhtar, K., S.N.M. Shah, A. Ali, S. Zaheer, F. Wahid, A. Khan, M. Shah, S. Bibi and A. Majid. 2014. Effects of humic acid and crop residues on soil and wheat nitrogen contents. Am. J. Plant Sci. 5: 1277-1284. https://doi. org/10.4236/ajps.2014.59141

Akhtar, K., W. Wang, A. Khan, G. Ren, M.Z. Afridi, Y. Feng and G. Yang. 2019a. Wheat straw mulching offset soil moisture deficient for improving physiological and growth performance of summer sown soybean. Agric. Water Manage., 211: 16-25. https://doi. org/10.1016/j.agwat.2018.09.031

Akhtar, K., W. Wang, A. Khan, G. Ren, S. Zaheer, T.A. Sial, Y. Feng and G. Yang. 2019b. Straw mulching with fertilizer nitrogen: An approach for improving crop yield, soil nutrients and enzyme activities. Soil Use Manage. 35: 526535. https://doi.org/10.1111/sum.12478

Akhtar, K., W. Wang, G. Ren, A. Khan, Y. Feng, G. Yang and H. Wang. 2019c. Integrated use of straw mulch with nitrogen fertilizer improves soil functionality and soybean production. Environ. Int., 132: 105092. https://doi. org/10.1016/j.envint.2019.105092

Ali, B., G.A. Shah, B. Traore, S.A.A. Shah, S.U.-S. Shah, S.G.M. Al-Solaimani, Q. Hussain, N. Ali, K. Shahzad, T. Shahzad, A. Ahmad, S. Muhammad, G.M. Shah, M. Arshad, R.A. Hussain, J.A. Shah, A. Anwar, M.W. Amjid and M.I. Rashid. 2019. Manure storage operations mitigate nutrient losses and their products can sustain soil fertility and enhance wheat productivity. J. Environ. Manage., 241: 468-478. https://doi.org/10.1016/j. jenvman.2019.02.081

Anonymous. 2007. Soil Survay of Pakistan. Land resource inventory and agricultural land use plan of Peshawar district. In soil survay of Pakistan. Land resource inventory and agricultural land use plan of Peshawar district. , ed. N.A.L.U. plan Lahore Pakistan.

Black, G.R. and K.H. Hartge. 1984. Bulk density. In: A. Klute (eds.), Method of sol analysis Part I. Physical and Mineralogical method of soil analysis Part I. $2^{\text {nd }}$ (edition), Madison, Wisconsin USA. Soil Sci. Soc. Am. Inc., pp. 363-376.

Bowles, T.M., V. Acosta-Martínez, F. Calderón and L.E. Jackson. 2014. Soil enzyme activities, microbial communities, and carbon and nitrogen availability in organic agroecosystems across an intensively-managed agricultural landscape. Soil Biol. Biochem., 68: 252-262. https://doi.org/10.1201/b17368-18

Bremner, J. and C. Mulvaney. 1982. Nitrogentotal. In: A.L. Page and D.R. Keeney (eds.), Method of soil analysis, Part II. $2^{\text {nd }}$ edition, Madison. WI: Soil Sci. Soc. Am. Inc., Madison, 
Wisconsin USA, pp. 595-624.

Fang, Y., B.P. Singh, D. Collins, B. Li, J. Zhu and E. Tavakkoli. 2018. Nutrient supply enhanced wheat residue-carbon mineralization, microbial growth, and microbial carbon-use efficiency when residues were supplied at high rate in contrasting soils. Soil Biol. Biochem., 126: 168-178. https://doi.org/10.1016/j. soilbio.2018.09.003

Federolf, C.P., M. Westerschulte, H.-W. Olfs, G. Broll and D. Trautz. 2016. Enhanced nutrient use efficiencies from liquid manure by positioned injection in maize cropping in northwest Germany. Eur. J. Agron., 75: 130138. https://doi.org/10.1016/j.eja.2016.01.016

Grant, C.A.,J.T. O’Donovan, R.E. Blackshaw, K.N. Harker, E.N. Johnson, Y. Gan, G.P. Lafond, W.E. May, T.K. Turkington, N.Z. Lupwayi, D.L. McLaren, B. Zebarth, M. Khakbazan, M. St. Luce and R. Ramnarine. 2016. Residual effects of preceding crops and nitrogen fertilizer on yield and crop and soil $\mathrm{N}$ dynamics of spring wheat and canola in varying environments on the Canadian prairies. Field Crops Res., 192: 86102. https://doi.org/10.1016/j.fcr.2016.04.019

Guo, L., G. Wu, Y. Li, C. Li, W. Liu, J. Meng, H. Liu, X. Yu and G. Jiang. 2016. Effects of cattle manure compost combined with chemical fertilizer on topsoil organic matter, bulk density and earthworm activity in a wheat-maize rotation system in Eastern China. Soil Tillage Res., 156: 140-147. https://doi.org/10.1016/j. still.2015.10.010

Ibrahim, M. and A. Khan. 2017. Phenology and maize crop stand in response to mulching and nitrogen management. Sarhad J. Agric., 33: 426-434. https://doi.org/10.17582/journal. sja/2017/33.3.426.434

Ibrahim, M., A. Khan, W. Ali and H. Akbar. 2020. Mulching techniques: An approach for offsetting soil moisture deficit and enhancing manure mineralization during maize cultivation. Soil Tillage Res. 200: 104631. https://doi. org/10.1016/j.still.2020.104631

Jan, M.T., P. Shah, P.A. Hollington, M.J. Khan and Q. Sohail. 2009. Agriculture research: Design and analysis: A monograph. Dep. Agron. Univ. Agric. Peshawar. pp. 85-91.

Keeney, D.R. and D.W. Nelson. 1982. Nitrogeninorganic form. In: A.L. Page, Miller and D.R. Keeney (eds.), Method of soil analysis.
Part 2, Madison. WI, USA. Am. Soc. Agron., pp. 643-698. https://doi.org/10.2134/ agronmonogr9.2.2ed.c33

Keller, M. and W. Koblet. 2015. Dry matter and leaf area partitioning, bud fertility and second season growth of Vitis vinifera L.: Responses to notrogen supply and limiting irradiance. VITIS J. Grapevine Res. 34: 77.

Khan, A., S. Fahad, A. Khan, S. Saud, M. Adnan, F. Wahid, M. Noor, W. Nasim, H.M. Hammad, H.F. Bakhat, S. Ahmad, M. Habib ur Rehman, D. Wang and O. Sönmez. 2019a. Managing tillage operation and manure to restore soil carbon stocks in wheat-maize cropping system. Agron. J., 111: 2600-2609. https://doi. org/10.2134/agronj2019.02.0100

Khan, A., M.T. Jan, M. Afzal, I. Muhammad, A. Jan and Z. Shah. 2015. An integrated approach using organic amendments under a range of tillage practices to improve wheat productivity in a cereal based cropping system. Int. J. Agric. Biol., 17: 467-474. https://doi.org/10.17957/ IJAB/17.3.13.248

Khan, A., M.T. Jan, A. Jan, Z. Shah and M. Arif. 2014. Efficiency of dry matter and nitrogen accumulation and redistribution in wheat as affected by tillage and nitrogen management. J. Plant Nutr., 37: 723-737. https://doi.org/10.10 80/01904167.2013.867989

Khan, A.,M.T.Jan, K.B. Marwat and M. Arif. 2009. Organic and inorganic nitrogen treatments effects on plant and yield attributes of maize in a different tillage systems. Pak. J. Bot., 41: 99108.

Khan, A., M.T. Jan, K.B. Marwat, M. Arif and A. Jan. 2008. Phenology and crop stand of wheat as affected by nitrogen sources and tillage systems. Pak. J. Bot., 40: 1103-1112.

Khan, A., A. Muhammad, A.A. Khan, S. Anwar and P.A. Hollington. 2019b. Nitrogen affects leaf expansion and elongation rates during early growth stages of wheat. Int. J. Agric. Biol., 21: 1117-1122.

Li, Y., J. Zhang, S.X. Chang, P. Jiang, G. Zhou, S. Fu, E. Yan, J. Wu and L. Lin. 2013. Long-term intensive management effects on soil organic carbon pools and chemical composition in Moso bamboo (Phyllostachys pubescens) forests in subtropical China. Forest Ecol. Manage. 303: 121-130.

Lin, Y., G. Ye, Y. Kuzyakov, D. Liu, J. Fan and W. 
Ding. 2019. Long-term manure application increases soil organic matter and aggregation, and alters microbial community structure and keystone taxa. Soil Biol.Biochem.,134:187-196. https://doi.org/10.1016/j.soilbio.2019.03.030

Liu, E., C. Yan, X. Mei, W. He, S.H. Bing, L. Ding, Q.Liu, S.Liu and T.Fan.2010.Long-term effect of chemical fertilizer, straw, and manure on soil chemical and biological properties in northwest China. Geoderma. 158: 173-180. https://doi. org/10.1016/j.geoderma.2010.04.029

Mclean, E.O., 1982. Soil $\mathrm{pH}$ and lime requirement. In: L.P. Albert and D.R. Keeney (eds.), Methods of soil analysis. Part II. Chemical and microbiological properties, Madison. WI: Soil Sci. Soc. Am. Inc., Madison, Wisconsin USA, pp. 209-223.

MNFSR. 2018. Agricultural statistics of Pakistan, Ministry of National Food Security and Research, Govt. of Pakistan. In Agricultural statistics of Pakistan, Ministry of National Food Security and Research, Govt. of Pakistan.

Muhammad, I., F. Khan, A. Khan and J. Wang. 2018. Soil fertility in response to urea and farmyard manure incorporation under different tillage systems in Peshawar, Pakistan. Int. J. Agric. Biol., 20: 1539-1547.

Muhammad, S., A. Anjum, M.I. Kasana and M.A. Randhawa. 2013. Impact of organic fertilizer, humic acid and sea weed extract on wheat production in Pothowar region of Pakistan. Pak. J. Agric. Sci., 50: 677-681.

Mukherjee, A. and A.R. Zimmerman. 2013. Organic carbon and nutrient release from a range of laboratory-produced biochars and biochar soil mixtures. Geoderma. 193194: 122-130. https://doi.org/10.1016/j. geoderma.2012.10.002

Nelson, D. and L.E. Sommers. 1982. Total carbon, organic carbon, and organic matter. In: A.L. Page (eds.), Methods of soil analysis. Part 2. Chemical and microbiological properties, Madison. WI: Am. Soc. Agron., pp. 539-579.

Odlare, M.,M.Pell and K. Svensson. 2008. Changes in soil chemical and microbiological properties during 4 years of application of various organic residues. Waste Manage. 28: 1246-1253. https://doi.org/10.1016/j.wasman.2007.06.005

Olesen, J.E., C.D. Børgesen, L. Elsgaard, T. Palosuo, R. Rötter, A. Skjelvåg, P. PeltonenSainio, T. Börjesson, M. Trnka and F. Ewert.
2012. Changes in time of sowing, flowering and maturity of cereals in Europe under climate change. Food Addit. Contam., 29: 1527-1542. https://doi.org/10.1080/19440049.2012.7120 60

Pan, F., W. Yu, Q. Ma, H. Zhou, C. Jiang and Y. Xu. 2018. Do organic amendments improve the synchronism between soil $\mathrm{N}$ supply and wheat demand? Appl. Soil Ecol., 125: 184-191. https://doi.org/10.1016/j.apsoil.2018.01.006

Saharan, V., R. Kumaraswamy, R.C. Choudhary, S. Kumari, A. Pal, R. Raliya and P. Biswas. 2016. $\mathrm{Cu}$-Chitosan nanoparticle mediated sustainable approach to enhance seedling growth in maize by mobilizing reserved food. J. Agric. Food Chem., 64: 6148-6155. https://doi. org/10.1021/acs.jafc.6b02239

Saikia, P., S.S. Bhattacharya and K.K. Baruah. 2015. Organic substitution in fertilizer schedule: Impacts on soil health, photosynthetic efficiency, yield and assimilation in wheat grown in alluvial soil. Agric. Ecosyst. Environ., 203: 102-109. https://doi.org/10.1016/j.agee.2015.02.003

Sainju,U.,B.Singh and W.Whitehead.2002.Longterm effects of tillage, cover crops, and nitrogen fertilization on organic carbon and nitrogen concentrations in sandy loam soils in Georgia, USA. Soil Tillage Res., 63: 167-179. https:// doi.org/10.1016/S0167-1987(01)00244-6

Schulz, H. and B. Glaser. 2012. Effects of biochar compared to organic and inorganic fertilizers on soil quality and plant growth in a greenhouse experiment. J. Plant Nutr. Soil Sci., 175: 410422. https://doi.org/10.1002/jpln.201100143

Sharif, M., R.A. Khattak and M. Sarir. 2002. Effect of different levels of lignitic coal derived humic acid on growth of maize plants. Commun. Soil Sci. Plant Anal., 33: 3567-3580. https://doi. org/10.1081/CSS-120015906

Singh, J.S., V.C. Pandey and D. Singh. 2011. Efficient soil microorganisms: a new dimension for sustainable agriculture and environmental development. Agric. Ecosyst. Environ. 140: 339-353. https://doi.org/10.1016/j. agee.2011.01.017

Tahir, M., M. Khurshid, M. Khan, M. Abbasi and M. Kazmi. 2011. Lignite-derived humic acid effect on growth of wheat plants in different soils. Pedosphere. 21: 124-131. https://doi. org/10.1016/S1002-0160(10)60087-2

Vashisth, A. and S. Nagarajan. 2010. Effect on 
germination and early growth characteristics in sunflower (Helianthus annuus) seeds exposed to static magnetic field. J. Plant Physiol., 167: 149-156. https://doi.org/10.1016/j. jplph.2009.08.011

Walker, D.J., R. Clemente and M.P. Bernal. 2004. Contrasting effects of manure and compost on soil $\mathrm{pH}$, heavy metal availability and growth of Chenopodium album L. in a soil contaminated by pyritic mine waste. Chemosphere. 57: 215-224. https://doi.org/10.1016/j. chemosphere.2004.05.020

Wen, Z., J. Shen, M. Blackwell, H. Li, B. Zhao and H. Yuan. 2016. Combined applications of nitrogen and phosphorus fertilizers with manure increase maize yield and nutrient uptake via stimulating root growth in a long-term experiment. Pedosphere. 26: 62-73. https://doi. org/10.1016/S1002-0160(15)60023-6

Zavattaro, L., L. Bechini, C. Grignani, F.K. van Evert, J. Mallast, H. Spiegel, T. Sandén, A. Pecio, J.V. Giráldez Cervera, G. Guzmán, K. Vanderlinden, T. D'Hose, G. Ruysschaert and H.F.M. ten Berge. 2017. Agronomic effects of bovine manure: A review of long-term European field experiments. Eur. J. Agron., 90: 127-138. https://doi.org/10.1016/j.eja.2017.07.010

Zhang, T., T. Wang, K. Liu, L. Wang, K. Wang and Y.Zhou. 2015. Effects of different amendments for the reclamation of coastal saline soil on soil nutrient dynamics and electrical conductivity responses. Agric. Water Manage., 159: 115-122. https://doi.org/10.1016/j.agwat.2015.06.002 